\title{
The Meaning of Housework (Domestic Sector) for The Indonesian Labor Woman's Husband in The Village of Dungmanten, Rejotangan Subdistrict, Tulungagung Regency
}

\author{
Singgih Susilo \\ Faculty of Social Science State University of Malang \\ Corresponding email: singgih.susilo.fis@um.ac.id \\ Wulan Amalia \\ Faculty of Social Science State University of Malang
}

\begin{abstract}
Lack of employment opportunities in the regions of origin, one of which led to some labor work overseas, becoming the TKI. The existence of labor, women working outside of the country gives the husband the consequences have a dual role as head of the family and as a housewife. The purpose of research to find out which aspects influenced the social context, the meaning of housework for her husband. Design analysis of this research uses phenomenology Alfert Schutz (1962). The research context which aspects influenced the understanding husband who worked in the household, that the subject's wife generally work in the country of Hongkong and Taiwan. Age of the oldest subjects 57 years (Sumani) and younger subjects aged 31 years (Talkim). Departure model generally uses a salary cut system. Income from the wife the highest overseas wife 7 million each month in. The subject's wife who works in Hong Kong and Taiwan. The husband received the housework because of factors (in order to motive). The understanding of the husband against housework was as half the unemployed do not perceptible.
\end{abstract}

Keywords-Meaning, husband, Indonesian Labor of Woman, households

\section{INTRODUCTION}

A large number of women working in foreign countries are inseparable from the job opportunities of domestic sector (households) that do not need too much skill or skill requirements. A Hugo also focuses his studies on Indonesian labor export program and research about women's migration as well as its impact on families in the regions of origin (Hugo, 1978). Research other Hugo was about the economic impact of labor migration of women towards regional development in East Flores, and found evidence of the donation remittance sent Labor Indonesia Flores woman is important for the economy of the region.

A large number of labor, women working abroad give consequences the husband has a dual role as head of the family and as a housewife. Research conducted by Daulay (2001) about the shifting patterns of gender relations in migrant families, shows that in the beginning of decision-making in a family showed a male dominance in decision-making in a family. The economic base of women migrants is a source of strength in bargaining gender relations. The impact of migration by Daulay (2001) in general, women migrant workers have enough power in determining the decisions concern the interests of the family. Housework starts cooking to washing the clothes into the work of the husband. Work that is not considered a light that is usually done by the mother is parenting, which in most cases, children were likely to be closer to the mother, and the role of the husband demanded should be able to make the child could close again, as experienced by the relationship between the child with his mother.

The phenomenon of a large number of husband allows his wife working abroad there were a few main factors, opportunities job opportunities in the country of destination more than male employment opportunities. Susilo (2012) in his study mentions destination countries such as Taiwan, Hong Kong and Saudi Arabia are more in need of women workers, because in these countries the much-needed manpower domestic sector. The results of such research are also supported by the incoming data from the Office of the village of Dungmanten, that most of the workforce is working outside the country are generally a lot of women who work in Taiwan and Hong Kong (Monograph of the village, 2014). The selection of the country's Taiwan and Hongkong as one of the dominant choice for labor, women in the village of Dungmanten, because the two countries have a higher wage standard than the standard wage countries Malaysia, Saudi Arabia, Brunei Darussalam and Singapore. In addition, in the country of Taiwan and Hong Kong is no protection for women by the State and for foreign labor.

The phenomenon mobility of labor, women working abroad are recognized in addition could be a little help solving the problem of employment in Indonesia and boost the country's foreign exchange, specifically can also to correct fate and self build TKI and his household in origin (Susilo, 2013). In the area of origin (village Dungmanten) limited employment opportunities and wage work are still very low is also an encouragement to carry out domestic work sector. The pull factor influenced the husband there in the space of a role as a homemaker, is the amount of remittance. Various conditions of context aspects influenced Husband TKI women in understanding the domestic sector work done, under-standing of the mind (related to the pattern of thinking) of self (TKI), 
purpose motives and motive causes of action in domestic work to interpret the Husband. To answer the problems of understanding husband against work on domestic sectors in this study used the perspective of Phenomenology. The perspective is different from the perspective of positivistic and rationalistic Unitarians.

Applications perspectives phenomenology basically learned researchers in knowledge cannot be separated from its moral views, both on a level to observe, gather data, analyze, or in making inferences. Perspective phenomenology has advantages and the ability to recite the understanding of domestic sector job for husband as subjective reality. The phenomenological approach requires a number of these interpretations, until finally able to get into the world of meaning (comprehension) and the world the concept of research subjects.

The concept of Phenomenology, first developed by Edmund Husserl, phenomenology of Alfred Schutz then appears, and the phenomenology of Peter 1. Berger (Ritzer, 1996). The third concept of Phenomenology has the specificity of the different studies, but the phenomenology of approach in accordance with the research focus on the meaning of domestic sector job for the husband is the phenomenology of Alfred Schutz developed by explaining that an understanding of because motives and in order to motivesThe main problems which become the focus of this research are: (1) how does the social context of the husband in understanding the role of domestic workers (2) how the meaning of housework for her husband.

\section{METHOD}

This study used a phenomenological perspective with social definition paradigm-oriented micro studies, developed by Alfert Schutz, namely in the world intersubjective in everyday life. This research aims to know the meaning of housework for the husband who abandoned his wife to work outside the country. To know the meaning of Phenomenology perspective used by social definition paradigm-oriented micro-studies developed by the paradigm Alfert Schutz, i.e. about world intersubjective in everyday life.Understanding (meaning the world) not regardless of the because motives and in order to motives. Understanding, according to Schutz is inseparable from the social context of the individual (because of motives).

The subject of research was all Husband Indonesian woman labor that is in the area of research. The number of subjects is determined when the subject's answers are already happening on the level of saturation. Extracting information of subjects using the method of the observation of participation and indepth interviews. The stages in this study are:

- the preparatory stage of the research,

- the stage of field research,

- the stage of data analysis (reduction of data, display data, and verify).

\section{FINDING AND DISCUSSION}

\section{A. Social context}

The social context of labor aspects influenced Indonesian labor (TKI) working abroad, became one of the factors because
TKI working abroad. In the perspective of Phenomenology Alferd Schutz (1962), such studies could not be detached from the social context as a because of motives and in order to motives. In the world of meaning by Schutz, explore the social context becomes necessary, when the motive cause (Because motives) individuals cannot separate from the past behind them. To that end, the necessary information about the social context of the subject's research, as described below.

Background research village (Dungmanten) is an area of dry land rice farming, generally in the region of the year only once harvest. The village of Dungmanten in the pass by two rivers that big enough with the technical irrigation, irrigation system, but the two river location is deeper than the surface of the agricultural land, River, layout cannot drain wetland. Thus, regional conditions, making a livelihood in the agricultural sector, in particular dryland farming cannot provide results, that meet the needs of the family economy.

One of the contexts of social aspects influenced Indonesia labor working abroad is a large number of family members in the farming community of the village of Dungmanten. A large number of family members provide the impact on children of the family, they only have a low level of education. A large number of subjects (the husband) who just educated elementary, there is even a subject that educated only up to grade two elementary like Sumani and Moh Suroto. While the highest was the subject of a High-School educational. The condition of agricultural land less favorable, the large number of family members, and low levels of education, is one of the motive causes subjects to allow their wives to work as migrant workers abroad and subjects receiving stay home and obliged to carry out household chores start cooking, cleaning, washing clothes, and shopping for daily cooking purposes.

\section{B. Understanding Husband Against Household Chores}

Housework by husbands who left his wife to go to work abroad as the TKI, contain a lot of understanding (meaning). Almost every subject has its own understanding. To understand this respective an understanding husband against housework uses analysis perspective phenomenology. The phenomenology of approach developed using phenomenology perpsekstif Alferd Schutz. Perpsekstif phenomenology Alferd Schutz holds that an action is based on various TKI individual mindsets, it has a new purpose and motive cause, and backed by a variety of situations and conditions.

Referring to Alferd Schutz theorist understanding Phenomenology, then understanding the remittance of the subject in the village of Dungmanten, give an idea of the existence of a pattern of understanding as follows (a) Household chores are interpreted by the husband as a job half the unemployed do not perceptible, and (b) the housework is interpreted by the husband as the main job.

- Housework is understood by the husband as a job halfunemployment not perceptible

Based on the results of research in the get that housework is understood by the husband as half the unemployment is not perceptible. It means that that the housework done by husband understood as the work time-consuming and tiring but when hired at others, income obtained could not suffice the needs of 
family life. Based on the foregoing the husband took a job, because of needs a paid per day already would be sure to the wife who works abroad.. This was done with the thinking in his work in his village, then income could be sufficient for the needs of his life. This understanding is affected (the social context) the existence of the family economy failed, and the motives of the purpose (in order to motivate) the magnitude of the income of the wife who work abroad. The expression of the understanding expressed by several subjects, among other things by Sumani as follows:

Sumani revealed that: "... As a male who plays the role of a housewife has an arduous task, every morning wake up early, after the dawn began to cook breakfast for the children of the school, I cook at once for lunch and dinner, washing clothes. Everyday life after housework, I worked for a builder, but it's been two weeks I don't work because no one is told to build a House (order). If there is no order to the times building I looks for fish to be sold, when the results of her catch a little I make as a side dish with dinner. Grief for many, especially housework is endless, including thinking tomorrow what side dish cooking. Often loneliness, sleeping alone, there are no friends as deliberations in the household. Liked when I cannot bear, family life needs to be fulfilled by remittances from his wife who works outside of the country..." (Interview, September 16, 2015)

This understanding is consistent with that proposed by Alferd Shutz that in phenomenology, is inseparable from the world of understanding Because of motive and in order motive. Understanding household chores as work half the unemployment discreet understood by other subjects such as Suroto, Sumani B, Ali Basuki, Ali Rasim, and Jemadi.

- Housework is understood by the husband as the main job

Understanding household chores by the husband as the main work gives the notion that housework us a preferred job, work every day by subject is finished after household chores completed. The subject feels comfortable because of the necessities of life for a day today has been remittances from people satisfied wife working abroad becomes a labor of Indonesia. Housework by husbands was understood as a major work, it means the housework when his wife is still there is the work of his wife, but after his wife became a labor of Indonesia abroad, housework being a responsibility of the husband, and is the main occupation, while the husband's job thus becomes the job done after the main work (housework) completed. Statements about "understanding of household chores as the main work" disclosed by Ali Basuki was born in 1976 in the village of Aryoblitar, Tulungagung Regency. The family of Ali Basuki Indonesia Labor family is, because 9 out of 13 siblings (brother and sister) working abroad as Indonesia's labor, while 4 other brothers and sisters. More Ali Basuki reveals the following:

Ali Basuki said that: "... My routine morning wake up exhausted prayer dawn woke my daughter aged 10 years.
Made breakfast and put on clothes to wear school uniform. Then usher went to school after dropping off the child to school me clean the House and wash clothes. Depleted homework, I am preparing to leave the village hall to work as an employee of the village. As a father and a mother to my children, $12 \mathrm{pm}$ I will pick the child's home school. Provides for lunch and accompany take a rest. The new $2 \mathrm{pm}$ I set off again to go to the fields to look for grass. Role as housewife almost nobody liked what yummy wife left abroad, all hassle because all I had to own that runs the household chores. But what could make me any servant Wife remains at its founding. The grounds for the future of a better economy and more. Liked that most household needs people satisfied with the wife's income as a labor of Indonesia abroad ... (Interview, 9 September 2015)

Based on the phrase, Basuki Ali has understood that housework as a liability for him because of his wife as a labor in abroad. Ali Basuki very understood that his wife's goal is to improve the economic life of his family, so her husband understands that job every day plays the role of housewife is exhausting, and not earning. Her work as a village hall in his income is very small, so this work is often done after the housework finished. The role of herself as a housewife is more important because of the remittances for the needs of his life is much larger

Other subjects at the sight of "household chores" meant as a "the main work" It is also expressed by the subjects of Hadi, who was born in 1969 in the village of Aryoblitar reveals the following.

Hadi Kusumo revealed that: "... The routine of everyday I am just taking care of two children, the first female child's 2nd class junior high school, and his younger brother boys 5th-grade elementary school as in the family is generally every morning wake up and have to cook her son to school. Before school, I have to prepare breakfast, I go on house cleaning and washing clothes. After my school administration preoccupied with household chores such as washing clothes clean housecleaning and cooking for lunch and evening. Household chores are finished, I started leaving for work as a builder if anyone told, Praise almost a month I am working on building a house belonging to $\mathrm{Mr}$. Harjoko. Actual work routines it is very tiring, but I must still undergo, because this is a deal with my wife before departure abroad"... (interview, 13 September 2015)

Hadi Kusumo expression of those that kept its main job of prioritizing as domestic workers, while the profession work as a builder do after homework stair finishes. Hadi statement raises Because the motive so that his family (wife) could work abroad because her income as a builder cannot meet the daily needs of the economy, let alone be able to save at all unthinkable. Hadi also contain phrases in order to motive, with himself is willing to play a role in domestic workers, hoping his wife abroad can earn a fixed and large every month, like last year with his wife working abroad her family could fix his house and the adequacy of his family's economic needs.

Understanding the husband not understanding regardless of the because motive is the poverty experienced by families in the 
districts of origin, and in order motive the size of the earnings of the wife who worked outside the country as women's Labor. This understanding is inseparable with what is expressed by Alferd Shutz (1962) that in phenomenology, world of understanding because of motive and in order motive. Understanding husband in interpreting this household work in line with the results of the research before (Susilo, 2014), on the meaning of remittance for the labor of Indonesia that the Understanding husband in interpreting this household work in line with the results of the research before (Susilo, 2014), on the meaning of remittance for the labor of Indonesia that the meaning was influenced by because the motives and in order motive.

\section{CONCLUSION}

Understanding husband in interpreting this household work in line with the results of the research before (Susilo, 2014), on Context aspects influenced the research Village (Dungmanten) is an area of dry land, these conditions cannot give sufficient results economic needs of families. The Community farmer of the village Dungmanten, has a large of family members, giving a low education level on the outbreak. A large number of subjects (the husband) who just educated Elementary School. This context is one of the motives causes (because of motive), the subject of allowing their wives to work becomes a labor of Indonesia abroad, with large income (in order to motive) and Subjects receiving the obligation to carry out household chores.
Referring to Alferd Schutz theorist understanding Phenomenology, so understanding the remittance of the subject in the village of Dungmanten, give an idea of the existence of patterns of understanding as follows: (a) the housework was understood by the husband as a job half the unemployed do not perceptible, and (b) the housework was understood by the husband as the main job.

This research was carried out with funding research BLU State University of Malang in 2015. Tanks submitted to research institutions the State University of Malang.

\section{REFERENCES}

[1] Daulay, Pardamean dan Singgih Susilo, 2010, "The mechanism of Survival of the household of the victim of the mud Lapindo", Journal of organization and management, Vol 2 September 2010, Jakarta, Universitas Terbuka (UT).

[2] Dungmanten Village Office, 2014, "Monograph Of The Village"

[3] Hugo, Graeme, J. 1978. "Population Mobility in West Java", Yogyakarta: Gadjah Mada University Press.

[4] Schutz, Alfred., 1962, "Collected Papers I: The Problem of Social Reality", Maurice Natanson, ed. TheHague: Nijhoff

[5] Susilo, Singgih, 2014, "Remittances of the Indonesian Migrant Workers on the Improvement of Family Welfare in Their Home Village", Asian Journal of Humanities and Social Sciences (AJHSS), 2(1): 61-67

[6] Susilo, Singgih, 2015, "The significance of Indonesian Workers against Remittances They Has Acquired: A Case Study in Bawean Island, Gresik, Indonesia”, Research on Humanities and Social Science (IISTE) Volume 2. 2015. 